DOI: 10.46340/eppd.2021.8.1.5

\author{
Anastasiia Bakanova \\ https://orcid.org/0000-0002-0911-7649 \\ Odesa I. I. Mechnikov National University, Ukraine

\section{RUSSIAN-UKRAINIAN CONFLICT \\ IN THE CONTEXT OF THE USE \\ OF "HARD POWER" IN INTERNATIONAL RELATIONS OF THE XXI CENTURY}

\author{
Анастасія Баканова \\ Одеський національний університет імені І. І. Мечникова, Україна

\section{РОСІЙСЬКО-УКРАЇНСЬКИЙ КОНФЛІКТ \\ У КОНТЕКСТІ ВИКОРИСТАННЯ «ЖОРСТКОЇ СИЛИ» У МІЖНАРОДНИХ ВІДНОСИНАХ ХХІ СТОЛІТТЯ}

The article analyzes the dynamics of Russian-Ukrainian relations since the collapse of the Soviet Union, and factors that have influenced these relations. We suppose that Russian Federation has been trying to build a geopolitical alliance of the countries that were the part of the USSR, and Ukraine has got a special place in these attempts. Russia supposed Ukraine to be its "buffer zone", and the place of preservation and increment of the assets. However, since 2004 Ukraine has changed its vector of internal and external policy towards democratic reforms and europeanity. The first attempt of the so-called "hard power" towards Ukraine was Russian influence on the President elections in Ukraine in 2010, when Russian policymakers and technologists were supporting their protégé Viktor Yanukovych to gain the position of the President. Russia got its benefits from the chaos inside Ukraine even before the war, as it became possible to influence Ukrainian politics while Ukraine adopted the democratic reforms in its internal policy. Transfer of Ukraine towards parliamentary-presidential republic instead of presidential-parliamentary one, free media and free flow of information gave Russia a chance to weaken the political system of Ukraine. All these issues are also connected with the Russian ambition to control the Black Sea and to control the gas supply system.

However, the events of the Revolution of Dignity have proved that Ukraine has selected its way towards political and economic modernization, while Russia has remained in its imperial past. Thus, Russia began its aggression against Ukraine, annexing Crimea and providing military support to the conflicts in other regions of Ukraine. It is supposed that Russia does not want Ukraine to become a part of its territory, but now its "hard" policy and constant facilitation of the war in the Donbas are aimed to preserve the instability inside Ukrainian political system, thus refraining Ukrainians from European and Euro-Atlantic integration.

Keywords: Russia, Ukraine, Russian-Ukrainian conflict, "hard power", aggression, influence.

Постановка проблеми. Відносини між Україною та Росією у всі часи були непростими, адже остання для реалізації своїх геополітичних амбіцій потребувала України завжди. I для задоволення зазначеної потреби наш північний сусід докладав чималих зусиль, не цураючись при цьому найбрудніших засобів та інструментів, які в підсумку призводили напруженості у взаєминах, аж до збройних конфліктів. І за часів Київської Русі, і Речі Посполитої, а тим паче в період Гетьманщини та у складі Російської імперії конфлікти різного ступеня інтенсивності були невід'ємними супутниками взаємовідносин двох країн. Не зникла ця тенденція і в XX та XXI ст.ст., набуваючи нових форм та проявів. «На війні всі засоби хороші», - говорить відома приказка, яка повною мірою втілюється у життя країною-агресором навіть сьогодні, в часи панування міжнародного права, пріоритету наднаціональних важелів впливу на суспільні відносини. Зважаючи на історичну 
складність у стосунках, викликану сукупністю чинників економічного, політичного, ментального тощо характерів, не дивно, що інтерес науковців-політологів, фахівців з міжнародних відносин та міжнародного права до цієї проблематики не згасає. Адже дослідження різних аспектів україноросійських взаємин було і залишається вкрай актуальною проблемою для науковців, особливо зараз, у період ескалації конфлікту та необхідності пошуку можливих засобів для його подолання.

Метою статті $\epsilon$ з'ясування передумов, підстав та особливостей російсько-українського конфлікту на сучасному етапі розвитку міжнародних відносин.

Виклад основного матеріалу. Риси, притаманні сучасній зовнішній політиці Росії, проявилися не відразу після приходу В. Путіна до влади. Але між 2003 і 2005 роками Кремль визначив Росію як самостійну велику державу, наполягаючи на тому, щоб США та ЄС ставилися до Росії як до рівного партнера ${ }^{1}$. Центральну Азію, Південний Кавказ та Україну Росія розглядала як поля бою із Заходом. Путін намагався використати новий постімперський націоналізм для підсилення своєї легітимності. Офіційний націоналізм Кремля знайшов своє відображення у таких тотожних поняттях як «суверенна демократія» й «енергетична супердержава», обидва з яких вийшли на перший план у 2005 році. Цілком логічно, що замість того, щоб намагатися інтегруватися із Заходом, Росія зробила своєю метою створення на території колишнього СРСР нової системи із центром у Кремлі.

У цьому світогляді особливе місце було відведено Україні. Росія не прагнула «возз'єднання» 3 Україною. «Лідери та еліта Росії бачать Україну як сукупність прибуткових активів і привабливих можливостей, а не як територію, яка повинна бути фізично приєднана до Росії» ${ }^{2}$. Утім значна частина росіян вбачала в Україні відокремлену, але не іноземну державу.

Значення України для Росії визначалося кількома основними чинниками, серед них була роль України як транзитного коридору для російських нафти і газу до Європи, економічні активи України від металів до телекомунікацій, пов'язування демократичної еволюції України з загрозою російському режимові (приклад українських революцій для російського суспільства). Ще одна важлива група чинників була пов'язана з російською військовою базою в Криму, зокрема, із базуванням Російського Чорноморського Флоту в Севастополі. Від часу російсько-українського договору 1997 року Україна була змушена розглядати велику кількість суперечок, спричинених розміщенням ЧМФ на ії території. На технічному рівні питаннями, що турбували українську владу, були наступні: статус і функціонування російських військових трибуналів в Криму, переміщення гідрографічного та навігаційного обладнання в Україну, інспектування ЧМФ Україною, кількість військового контингенту, який розміщувався в Україні, інвентаризація займаної площі та обладнання, відданого в лізинг ЧМФ, угода про спільні дії в екстрених випадках. Деякі з вищезазначених питань, наприклад, переміщення гідрографічного та навігаційного обладнання в Україну, були принципово виключені російською стороною з програми російсько-української підкомісії щодо російського ЧМФ до закінчення терміну лізингу в 2017 році $^{3}$. Інші питання, такі, як режим перетину кордону для російських військових і модернізація флоту, були змістом перемовин вищого рівня.

У 2003 році Москва зробила спробу встановити контроль над Україною. Проект ЄЕП (Росія, Білорусь, Казахстан, Україна), який спочатку декларував мету економічного союзу, зрештою мав створити політичний та безпековий союз під егідою Москви ${ }^{4}$.

Розробляючи свою стратегію напередодні президентських виборів 2004 року в Україні, Росія покладала надії на єдиного кандидата від «партії влади», висунутого попереднім президентом Л. Кучмою - прем'єр-міністра $\quad$ В. Януковича. Кремлівський політтехнолог $Г$. Павловський зазначив, що умови його контракту з адміністрацією президента РФ передбачали безпосередньо забезпечення перемоги Януковича на виборах ${ }^{5}$. Поразка Януковича була непередбачена. Кремль

\footnotetext{
${ }^{1}$ Piontkovsky, A. (2011). Ukraine between Russia and the EU. National Security and Defence Journal $<$ www.razumkov.org.ua/...journal/NSD_133-134_eng_1.pdf $>$ (2021, січень, 28).

2 Trenin, D. (2007). Russia and Ukraine. The New Eastern Europe: Ukraine, Belarus, Moldova. Vienna: Centre for Transatlantic Relations/Austrian Institute for International Affairs, 197.

${ }^{3}$ Radiosvoboda (2008). У Європі порівнюють Украӥну з Венесуелою. Беніта Ферреро-Вальднер: «Обнадіювати

Україну вступом до СС- погана ідея» (Огляд європейської преси)

$<$ http://www.radiosvoboda.org/a/1118833.html> (2021, січень, 28).

${ }^{4}$ Putin, V. V. (2011). New Integration Project for Eurasia - A Future That Is Being Born Today. Izvestia <

https://isij.eu/article/new-integration-project-eurasia-future-being-born-today> (2021, січень, 28).

5 Trenin, D. (2007). Russia and Ukraine. The New Eastern Europe: Ukraine, Belarus, Moldova. Vienna: Centre for Transatlantic Relations/Austrian Institute for International Affairs, 202.
} 
спробував виправити ситуацію, називаючи революцію «спецоперацію» США й дискредитуючи помаранчеву коаліцію.

Метою Москви стала нейтральна Україна, тобто пізня версія Фінляндії, розташованої між Росією і Заходом. Скоро Москва розробила нову тактику, засновану на чотирьох основних елементах: 1) на офіційному рівні ігнорувати київську прозахідну політику, особливо амбіції щодо НАТО; 2) таємно провокувати дестабілізацію всередині України, поглиблюючи історичні відмінності регіонів країни і стримуючи іiї рух до НАТО; 3) використовувати прямий економічний, соціальний і культурний тиск як інструменти зовнішньої політики; 4) пропонувати допомогу в забезпеченні безпеки України завдяки формам співпраці з СНД або двостороннім каналам.

Політична реформа в Україні, яку було здійснено після Помаранчевої революції, полегшила основні завдання РФ. Україною як парламентсько-президентською республікою керували внутрішньо слабкі коаліційні уряди, які традиційно представляли інтереси кількох олігархічних груп. Згідно з одним українським інсайдером, «реальна політика в Україні - це газова політика. Якщо ви керуєте газом, ви керуєте головними політичними групами в Україні» ${ }^{1}$. Москва також черпала впевненість у тому, що пронатовські настрої в Україні були ослаблені, а більшість іiі населення, за винятком західних регіонів, не розглядала Росію у якості супротивника.

Офіційно Москва розглядає незалежність України як щось «неправильне та тимчасове». О. Сушко ще в серпні 2008 року зазначав про можливий сценарій російської стратегії: «Якщо Захід пробачить Росії грузинську війну, тоді вторгнення «танків 3 підтримання миру» на територію України стане просто питанням часу. Коли Росія розпочала масове введення армії на грузинську територію, конфлікт обернувся на геополітичну війну, націлену на скасування чинного світового порядку. Насамкінець стратегія реваншу спричинила б занепад російської державності, однак до цього Росія може спричинити велику кількість конфліктів. Росіяни свідомо готуються до війни з Україною. У Росії завжди відсутність війни призводить до зниження рівня національної гордості. Періоди національного ентузіазму були майже повністю пов'язані з війнами. В. Путін почав з Чечні, В. Медвєдєв з Грузії. Гасло «Там наші громадяни!» допомагає створити відчуття квазізаконності, якої достатньо для російських громадян. Росіяни скажуть у кращому випадку: «Американці роблять так само». У випадку військових дій проти України пересічні росіяни підтримають своє армійське та політичне керівництво. Їм будуть говорити, що це не війна проти братського народу, а війна проти іiі «злодійського уряду» ${ }^{2}$. У липні 2009 року у Держдумі Росії заступник голови С. Багдасаров сказав 3 приводу 300-річчя Полтавської битви: «Наступні президентські вибори на Україні будуть не тільки черговими виборами президента, вони будуть нашою Полтавою-2» ${ }^{3}$. У цей час $80 \%$ росіян підтримували політику В. Путіна щодо України.

Для Росії принциповим стало питання про продовження права на базування Чорноморського флоту в Криму після 2017 року, коли термін дії чинного договору, підписаний у 1997 році, добігав кінця. Також важливою для РФ була можливість збереження використання радару раннього попередження у Севастополі (другий радар такого типу був у Мукачеві). Ще одним подразником був кордон в Азовському морі, в зоні Керченської протоки. У жовтні 2006 року Путін заявив про можливість розширення базування ЧМФ в Криму після закінчення договору в 2017 році ${ }^{4}$. Це стало передбачуваним продовженням масових протестів проти навчань Сі Бриз у Криму в 2006 році. Вперше з 1997 року такі протести закінчилися скасуванням спільних військових навчань із НАТО за програмою Партнерства Заради Миру. Російські розвідувальні служби та персонал ЧМФ безпосередньо брали участь у підготовці антинатовських виступів спільно зоднопартійцями В. Януковича 5 . Росія поступово почала віддавати перевагу інструментам жорсткої сили, але вповні це почало проявлятися у 2013 році.

\footnotetext{
${ }^{1}$ Moulioukova, D. (2011). Dialectic Relation between Foreign Policy and Russian National Identity. Miami-Florida European Centre of Excellence, 11, 9, 17.

${ }^{2}$ Сушко, О. (2008). Україна - наступна? Українська правда

$<$ http://www.pravda.com.ua/articles/2008/08/12/3517426/?attempt=1?attempt=2> (2021, січень, 28).

${ }^{3}$ Volovych, O. (2014). The Agony of the Empire. Borysfen Intel <http://bintel.com.ua/en/guests/agonija-imperii/> (2021, січень, 28).

${ }^{4}$ Radiosvoboda (2008). У Європі порівнюють Украӥну з Венесуелою. Беніта Ферреро-Вальднер: «Обнадіювати Украйну вступом до СС- погана ідея» (Огляд європейської преси) <http://www.radiosvoboda.org/a/1118833.html> (2021, січень, 28).

${ }^{5}$ Kovalova, E. (2007). Ukraine and Its Neighbors. Ukraine's Role in Changing Europe. The New Eastern Europe: Ukraine, Belarus, Moldova. Washington, 180.
} 
Коли Путіну вдалося усадити в президентське крісло України В. Януковича, біля $70 \%$ економічного потенціалу України керувалося російським капіталом. У Верховній Раді та уряді регіонали та комуністи створили сильне проросійське лоббі. Російські спецслужби встановили контроль над силовими структурами України - армією, поліцією, Службою безпеки. Крім того радіо та телебачення демонстрували переважно російські витвори, що нав'язували російський менталітет та підривали українську ідентичність.

21 листопада 2013 року Кабінет Міністрів України оголосив про призупинення підготовки до підписання угоди про асоціацію з СС й відкладення угоди в уряді пояснили тиском Росії та бажанням України мінімізувати економічні ризики. Янукович відкрито наполягав на тристоронніх переговорах Україна-Росія-СС. Кремлю здавалося, що він виграв фінальну битву за Україну: 17 грудня 2013 року В. Янукович у Москві підписав домовленості, за якими він відмовлявся від європейської інтеграції в обмін на зниження цін за російський газ.

Але за цим послідкував Євромайдан. Москва розраховувала, що Янукович здатен силоміць відновити контроль над країною, а коли цього не сталося, Кремль перейшов до нових заходів. Мало хто міг передбачити, що, як тільки новий уряд в Україні буде сформований, Кремль вдасться до неспровокованого збройного втручання. Чому Москва вирішила це зробити? На думку О. Брусиловської та І. Коваля, по-перше, В. Путін не міг прийняти втрату України; по-друге, Москва вважала, що якби на той момент нічого не вдалося змінити, вона почала би поступово втрачати свій статус у світі, отже діяти вона мала негайно ${ }^{1}$.

Для всіх стала потрясінням швидкість, з якою можна змінити політичну ситуацію в Свропі. Стабільність й міжнародне право поступилися реалістській «моці». Пріоритетом для політичних діячів у Кремлі стало відновлення геополітичного контролю над областями, суміжними з Російською Федерацією й над сферами впливу, що існували за радянських часів. Російське лідерство пробувало втримати сусідів Росії (Грузія й Україна, як у 1990-ті роки країни Балтії, Польща, Чеська Республіка й Словаччина) від зміщення в західну сферу впливу. Кремль був переконаний, що Центральна й Східна Європа має залишитися російською сферою впливу, i дії Заходу розглядалися як заперечення лідерства РФ².

У 2013 році Кремль оголосив, що в Україні мало місце «збройне захоплення влади», хоча обрана у жовтні 2012 року Верховна Рада залишалася чинною у повному складі. 3 лютого 2014 року Кремль почав послідовно дестабілізувати ситуацію в Україні. Агенти ФСБ організовували сепаратистські рухи у Закарпатті, Криму та на південному сході України. Крим було захоплено майже без пострілів. Заколот у Донбасі був підготовлений російськими спецслужбами заздалегідь й він став можливий через пряму військову агресію Росії ${ }^{3}$.

6 березня 2014 року парламент Криму прийняв рішення 1702-6/14, яке передбачало проведення референдуму 16 березня. Влаштований за 10 днів, без передбаченого оголошення, референдум мав ознаки таких порушень, як непрозорість щодо складу списків виборців і виборчих комісій, відсутність міжнародних спостерігачів. Окрім того, ініціатива не пропонувала можливості такого вибору як статус-кво, залишаючи тільки дві можливості: 1) приєднатися до Російської Федерації як федеральний суб'єкт; 2) повернутися до Конституції Криму 1992 року й бути «невід'ємною частиною України». Однак, відповідно до Конституції 1992 року Крим мав повні верховні повноваження щодо встановлення відносин з іншими державами, що означало: незалежно від вибору кримчан, референдум фактично означав переривання зв'язку з Україною. Референдум було організовано самопроголошеним й самозваним «головою Криму» С. Аксьоновим, чиє назвисько Гоблін нагадувало про його злочинне минуле. Референдум було проведено тільки на Кримському півострові, що недвозначно суперечило Конституції України, оскільки питання змін кордонів країни може бути вирішено винятково на національному референдумі. Місцеві мешканці, кримські татари, бойкотували референдум. Нарешті, референдум було проведено під загрозою зброї так званих «зелених чоловічків», фактично російських бійців, які пізніше одержали медалі честі від В. Путіна

\footnotetext{
${ }^{1}$ Брусиловська, О. І., Коваль, І. М. (2018). Російсько-українські відносини у період інформаційної війни. Міжнародні відносини та зовнішня політика в еру «пост-правди». Київ: Вадекс, 39.

${ }^{2}$ Darczewska, J. (2014). The Information War on Ukraine: New challenges. Cicero Foundation Great Debate Paper, $14 / 08,5$.

${ }^{3}$ Brusylovska, O. (2015). Russian-Ukrainian conflict. First stage: propaganda war. Вісник ОНУ. Серія: Соціологія $і$ політичні науки, 20, 2 (23), 60.
} 
за «повернення Криму». Насамкінець, результати референдуму було сфальсифіковано ${ }^{1}$. Анексію Криму не визнало міжнародне співтовариство, навпаки, Генеральною Асамблеєю ООН вона була оголошена правопорушенням територіальної цілісності України. Результати референдуму були визнані тільки декількома країнами, які мали особливі зв'язки з Росією. Враховуючи все вищезазначене, заяви про законність анексії Криму суперечать міжнародному праву.

Другою частиною планів РФ було створення так званої «Новоросії». Російські агенти, куратори сепаратистів, одержали сигнал виступити проти Києва. Поліція й Служба безпеки в Донецькій і Луганській областях майже повністю перейшли на бік сепаратистів. Завдяки підтримці комуністів і регіоналів було оголошено «Донецьку Народну Республіку» і «Луганську Народну Республіку», а 11 травня 2014 року було проведено «референдум» щодо їх незалежності. Лідери сепаратистів дійшли згоди, щоб об'єднати ці «республіки» у федеральну державу «Новоросія». Поняття «Новоросія» означало конфедерацію самозваних республік Донецька й Луганська. В. Путін вперше назвав цю частину України «Новоросія» тільки 17 березня 2014 року, після анексії Криму, а 11 вересня він відвідав церкву в Москві, щоб «запалити свічки за загиблих у боротьбі за Новоросію»².

Але дуже скоро сталися невдачі у сценарії «народного повстання» на південному сході. Не допомогло навіть доправлення через російсько-український кордон сотень російських офіцерів та десятків тисяч добровольців, а також зброї, боєприпасів і фінансів. Пік смертності в серпнівересні стривожив Кремль: незважаючи на цензуру, суспільство довідалося про труни, що прибували у Росію з України, секретні похорони солдат, убитих на війні на сході України. Комбінація військових жертв і економічного спаду викликала проблеми для режиму. Санкції вразили Росію, і Москва зрозуміла, що посилення прямого тиску на Україну могло скінчитися подальшими санкціями. Крім того, омріяний «міст через Херсонщину та Одещину» до Криму міг бути створений лише шляхом відкритої війни. Москва прагнула перешкодити Україні рухатися на Захід, але не була певна щодо кращого способу домогтися цього ${ }^{3}$. Мінські угоди (12 лютого 2015 року) були частково ініціативою Москви, і Москва могла таким чином представити власному суспільству свій фактичний відступ як перемогу.

Деякі коментатори й навіть деякі українські політики запропонували радикальне рішення: відмовитися від Донбасу в цілому. Це звільнило би Київ, допомогло би зосередитися на реформах і заощадити кошти. Але незалежність Донбасу - це опція, якої Москва не прагла. Росія прагла мати переваги, а не обтяжувати себе новими зобов'язаннями на Донбасі ${ }^{4}$. Мета Росії полягала у тому, щоб зберігати «гарячу точку» на території України, що стало би перешкодою на шляху до НАТО, й мати криміналізовану область, яка постійно підриватиме державний розвиток України. Для Москви Донбас став тим самим, що Південна Осетія та Придністров'я.

Для досягнення цілей Кремлю було достатньо підтримувати сепаратистів Донеччини та Луганщини збройними силами, економічним, політичним, інформаційним шляхом. Це обернулося війною на виснаження: терористичні дії мали тривати, доки за задумом Москви українське населення буде знесилене, обурене й готове на з'єднання з Росією задля закінчення війни. Для виконання такої програми Росія була готова й далі витрачати всі свої ресурси: зброю, боєприпаси, гроші й бійців, для яких військова кампанія на південно-східній Україні стала й джерелом доходу й можливістю здобути бойовий досвід.

На думку Е. Уокера, професора Університету Берклі, немає «ніякого шляху для України відновити контроль над Донбасом. У недалекому майбутньому життя на Донбасі буде жахливе й набагато гірше, аніж в інших невизнаних державах. Насамперед, Донбас набагато більший, ніж будь-яка інша невизнана територія. По-друге, він має дуже довгий кордон з Росією. Це дає деякі економічні вигоди для Донбасу, але цей кордон важко захистити. Третій фактор- рівень мілітаризації суспільства й факт, що військові сили поділені на ворожі угрупування. Четвертий фактор полягає у тому, що є численні складні об'єкти промисловості на Донбасі, більшість з яких уже зруйновано. Навіть якщо ми дотримуємося оптимістичного сценарію - війна закінчилася і регіон одержав масивні інвестиції - все-таки буде дуже дорого його відновити. Малоймовірно, що

\footnotetext{
1 Там само, 62.

2 Там само, 63.

${ }^{3}$ Liik, K., Wilson, A. (2014). What will happen with Eastern Ukraine? Policy Memo. The European Council on Foreign Relations, $119<$ https://ecfr.eu/wp-content/uploads/What_Will_Happen_to_Eastern_Ukraine.pdf $>$ (2021, січень, 28). ${ }^{4}$ Там само.
} 
Росія погодилася б інвестувати істотні кошти у відновлення регіону, тому що це не $є$ іiї метою. П’ятий серйозний фактор, який продовжить підривати ситуацію, це політична метушня, яка, ймовірно, домінуватиме на Донбасі найближчим часом; я не бачу жодної можливості існування політичної влади, яка б об'єднала людей» ${ }^{1}$.

За російською логікою Україна, як й інші країни НС€ та Південного Кавказу, має прийняти свій статус буферної зони. Нейтральний статус України насамперед означає здатність Росії більше впливати на Україну, ніж ЄС. Статус буферної держави посилив би безвихідне становище. Але й Мінський протокол було неможливо виконати, тому що сепаратисти та Кремль цього не хотіли.

Таким чином, можна винести кілька висновків із стратегії переходу до жорсткої сили Росією. По-перше, шляхи Росії й України розійшлися. 3 середини 2000-х років Росія прагнула досягти світового лідерства, а Україна рухалася убік Європи. Після 2004 року Україна вистроїла плюралістичну політичну систему: iї партії займалися реальною політичною боротьбою; судова система була далеко не ідеальною, але не залежала від політичної влади; засоби масової інформації були вільними; бізнес-інтереси, у тому числі інтереси східноукраїнських магнатів, частіше було зорієнтовано на Захід; все більше українців ідентифікували свої цінності з європейськими. Україна в односторонньому порядку відкрила себе для безвізового режиму з країнами ЄС та Північної Америки. Отже, Україна просувалася шляхом економічної і політичної модернізації, тоді як Росія не змогла визнати повноцінним життя «після імперії»; великодержавні претензії призвели до авантюр у зовнішній політиці й грубого нівелювання національних інтересів на користь невеличкої групки осіб, що володіли водночас владою та власністю.

Російсько-український конфлікт розпочав новий етап не тільки удвосторонніх, а й у міжнародних відносинах. Анексією Криму Росія зруйнувала Будапештський меморандум; підірвала репутацію ОБСЄ бойкотом Місії щодо України й нехтуванням Мінськими угодами; підірвала основну функцію ООН, використовуючи вето у Раді Безпеки. Головний партнер Росії у торгівлі, інвестор і колись стратегічний союзник - СС - став її критиком. До 2014 року близько $75 \%$ прямих іноземних інвестицій у Росію і майже 50\% російської зовнішньої торгівлі були пов'язані з країнами ЄС. У 2014 році Росію було виключено з Великої Вісімки, у зв'язку з чим вона втратила право голосу у ПАРС (до 2019 року). Обговорення питання російського членства в ОЕСР й нової угоди з СС було припинено; стратегічне партнерство з СС існує тільки на папері; Рада Росія-НАТО втратила чинність.

Висновки. Наведене вище яскраво демонструє, що Росія не тільки порушила численні двосторонні угоди з Україною, а також знецінила важливі багатосторонні мережі й організації, спаплюжила принципи та постулати, виробленні ще в середині минулого століття. 3'ясувалося, що наявність міжнародних норм, на жаль, не означає їх неухильне дотримання всіма країнами, а їх порушення далеко не завжди призводять до відповідальності. Залишається сподіватися, що російсько-український конфлікт змусить світову спільноту переглянути концептуальні засади функціонування міжнародних відносин на сучасному етапі, зрозуміти прогалини в міжнародному законодавстві та інші проблеми, які унеможливлюють викорінення подібних агресивних проявів у цивілізованому суспільстві. Так само це спонукатиме до подальших наукових досліджень, пошуків та розвідок в напрямку подолання описаного у статті конфлікту, а також недопущення аналогій у майбутньому.

\section{References:}

1. Brusylovska, O. (2015). Russian-Ukrainian conflict. First stage: propaganda war. Visnyk ONU. Seriya: Sotsiolohiya $i$ politychni nauky [ONU Bulletin. Series: Sociology and Political Science], 20, 2 (23), 60. [in English].

2. Darczewska, J. (2014). The Information War on Ukraine: New challenges. Cicero Foundation Great Debate Paper, 14/08, 5. [in English].

3. Kovalova, E. (2007). Ukraine and Its Neighbors. Ukraine's Role in Changing Europe. The New Eastern Europe: Ukraine, Belarus, Moldova. Washington, 180. [in English].

4. Liik, K., Wilson, A. (2014). What will happen with Eastern Ukraine? Policy Memo. The European Council

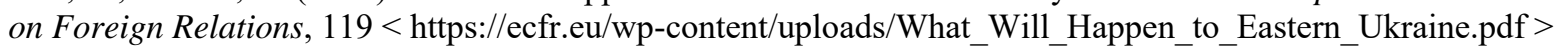
(2021, January, 28). [in English].

5. Moulioukova, D. (2011). Dialectic Relation between Foreign Policy and Russian National Identity. Miami-Florida European Centre of Excellence, 11, 9, 17. [in English].

\footnotetext{
1 Уокер, Э. (2014). Будь украинцы циничнее, они бы отдали Донбасс Путину. Liga: Business $<$ http://biz.liga.net/all/all/intervyu/2873463-uoker-bud-ukraintsy-tsinichnee-oni-by-prosto-otdali-donbass-putinu.htm> (2021, січень, 28).
} 
6. Piontkovsky, A. (2011). Ukraine between Russia and the EU. National Security and Defence Journal <www.razumkov.org.ua/...journal/NSD_133-134_eng_1.pdf> (2021, January, 28). [in English].

7. Putin, V. V. (2011). New Integration Project for Eurasia - A Future That Is Being Born Today. Izvestia $<$ https://isij.eu/article/new-integration-project-eurasia-future-being-born-today> (2021, January, 28). [in English].

8. Radiosvoboda (2008). U Yevropi porivnyuyut Ukrayinu z Venesueloyu. Benita Ferrero-Valdner: «Obnadiyuvaty Ukrayinu vstupom do YES - pohana ideya» (Ohlyad yevropeyskoyi presy) [In Europe, Ukraine is compared to Venezuela. Benita Ferrero-Waldner: "Encouraging Ukraine to join the EU is a bad idea" (European Press Review)] $<\mathrm{http}$ //www.radiosvoboda.org/a/1118833.html> (2021, January, 28).

9. Trenin, D. (2007). Russia and Ukraine. The New Eastern Europe: Ukraine, Belarus, Moldova. Vienna: Centre for Transatlantic Relations/Austrian Institute for International Affairs. [in English].

10. Volovych, O. (2014). The Agony of the Empire. Borysfen Intel <http://bintel.com.ua/en/guests/agonija-imperii/> (2021, January, 28). [in English].

11. Brusylovska, O. I., Koval, I. M. (2018). Rosiysko-ukrayinski vidnosyny u period informatsiynoyi viyny [RussianUkrainian relations during the information war]. Mizhnarodni vidnosyny ta zovnishnya polityka v eru "post-pravdy» [International relations and foreign policy in the era of "post-truth"]. Kyiv: Vadex.

12. Sushko, O. (2008). Ukrayina - nastupna? [Is Ukraine next?]. Ukrayinska pravda [Ukrainian Pravda] $<$ http://www.pravda.com.ua/articles/2008/08/12/3517426/?attempt=1 ?attempt=2> (2021, January, 28).

13. Uoker, E. (2014). Bud ukraintsy tsinichneye, oni by otdali Donbass Putinu [If Ukrainians were more cynical, they would give Donbass to Putin]. Liga: Business <http://biz.liga.net/all/all/intervyu/2873463-uoker-bud-ukraintsytsinichnee-oni-by-prosto-otdali-donbass-putinu.htm $>$ (2021, January, 28). 